\section{Ankara University Faculty of Educational Sciences Journal of Special Education}

2022, 23(2), 295-317

\title{
The Perceptions of Individuals with Intellectual Disability toward Workplace Environment and Practices
}

\begin{abstract}
Adel Alanazi iD 1
Abstract

Introduction: The examination of the literature on the people with intellectual disabilities reveals significant findings on the policies developed in Saudi Arabia to address their needs, changes in the Saudi culture to accommodate people with disabilities, proactive measures taken by the government to guide behaviors at workplace and discrimination by the employers. However, despite substantial study on these aspects associated with disability, the perceptions of adults with disabilities aspiring for jobs is absent.
\end{abstract}

Method: In this respect the aim of this study is to determine the perceptions of 10 people with intellectual disabilities toward workplace environment and practices in Saudi Arabia. The participants were selected through the help of the Ministry of Human Resources and Social Development, Riyadh. Only 3 participants were male, the rest were female aged 20-26 years and suffering from mild disability. The data were collected through in-depth interviews and then analyzed thematically.

Findings: The findings indicate that the participants encounter recruitment challenges in terms of skills requirements, lack of trust from employers, perception of inability to function as required, perceptions of low skills, and low salaries.

Discussion: There are many reasons that can explain why such occurrences take place in organizations. The literature details that employers usually find it problematic to hire employees with disabilities and would rather pay them even when not working for the fear that people with disabilities might fail the performance test during the interviews.

Conclusion: The government and the corporate world should apply these findings in formulating policies geared to improving the well-being of jobseekers with disabilities and employees in the Saudi Arabia.

Keywords: Perceptions, perceptions about work, intellectual disabilities, workplace environment, practices.

To cite: Alanazi, A. (2022). The perceptions of individuals with intellectual disability toward workplace environment and practices. Ankara University Faculty of Educational Sciences Journal of Special Education, 23(2), 295-317. https://doi.org/10.21565/ozelegitimdergisi.776646

${ }_{1}^{1}$ Corresponded Author: Assistant Professor, Special Education Department, Jouf University, asalanazi@ju.edu.sa, https://orcid.org/0000-0002-6378-1073 


\section{Introduction}

The relationships between individuals with and without disabilities are underpinned by cultural and social issues that characterize a society. Globally, 650 million people are estimated to be living with a disability and approximately a third of children with disabilities across the developing world do not have access to appropriate disability care in the form of services and amenities (Unite for Sight, 2016). Furthermore, according to Aiden and McCarthy (2014), stigmas and beliefs derive from the cultural and social beliefs of a specific society, this observation explains the difference in the perpetuation of stigma against disability in the United Kingdom (UK) as compared to Saudi Arabia, which is a result of differences in cultural and social perceptions. Regarding the comparison between the West and the East, the UK and the Saudi contexts are relevant for either case. Mackelprang and Salsgiver (2015) found that there has been a tremendous transformation in the perceptions of the Western world toward disability. The authors articulate three main steps through which the transformation took place. The first phase took place at the time of industrial revolution in the 18th century when there was negligible segregation of people with disability by the society. At that time, people with disabilities were believed not to be as functional as other people due to laziness (Cubbage, 2017). These perceptions toward people with disabilities were also associated with the beliefs that they were suffering as a result of their parents' sins. Such perceptions were transformed during the second phase (known as institutional phase), when society found it necessary to start accommodating people with disabilities, to the extent of constructing medical institutions to cater for their needs. Furthermore, the changes in the second phase led to the culture of accommodating individuals with disabilities people in special care units to ensure that they were removed from general social engagement (Mackelpang \& Salsgiver, 2015). At this time people living with disabilities were termed dependent and weak; however, grouping them in special care centers even led to further segregation that conflicted with the real intent of helping them (ElHady, 2011). The third phase occurred in the later 20th century, when there was more effort to make disability more acceptable to the society through complete elimination of stigmatization (Algahtani, 2017). This phase led to the development of technological and structural changes, which were aimed at enabling people with disabilities to be more independent. All these phases took place in the Western world, while some elements of segregation still exist. Further analysis of the Saudi context is necessary to create a comparison with Western perceptions to individuals with disabilities.

It has also been examined from the findings of the prevailing literature that the people with disabilities in Saudi Arabia continue to encounter several cultural and societal barriers to social inclusion in the Kingdom (Yousef, 2018). A severe disregard to the persons with disabilities has been observed in the Kingdom, which can also be attributed to the limited measures taken by the government to improve the quality of life of the persons with disabilities. There is also an absence of a reliable government helpline to assist and guide people with disabilities in the Kingdom or a public document that lays down the rights of the persons with disabilities. In addition, in Saudi Arabia there is a lack of central or public register to offer financial or social support services to them (Yousef, 2018). It is also examined by Alnahdi (2018) that adequate laws are absent to accommodate persons with disabilities in Saudi Arabia. In that region, there are no national laws to combat discrimination against people with disabilities by employers (Mansour, 2009). This absence further suppresses the voices of the individuals with disabilities aspiring to be employed. In addition, it has also been examined from the prevailing literature that disability research studies in Saudi Arabia have focused mainly on their rehabilitation and treatment in society. There is a severe absence of research on employment policy for people with disabilities (Alkhouli, 2015). The issue of disability in the Kingdom is a significant concern for the policymakers of the country wherein the approximate $3.73 \%$ of the population suffering from functional disabilities having the substantial potential to seek economic independence continue to be dependent (Alkhouli, 2015). These findings further highlight the gravity of the issue of disability in Saudi Arabia and the need for significant research in this area. In addition, the perceptions of the people with such disabilities can be examined in order to provide appropriate remedies to assist them in securing adequate employment opportunities and social inclusion at workplaces.

Moreover, since the current research is addressing a Saudi perspective, it is equally important to evaluate the cultural impact of Saudi society on the status of disability in the Kingdom. In their study, Grames and Leverentz (2010) argued that whilst the Western countries are working toward creating positive improvements to the wellbeing of individuals with disabilities through policy development, most of the Arabian countries are still lagging behind due to an inability to fully contain stigma against individuals with disabilities. In addition, the lack of development of a social model of care for individuals with disabilities in Arab countries is an attitudinal phenomenon that has existed for some time now (Alajmi \& Al-Batal, 2016). Another significant example has been covered lately in the literature by Hannon (2017), elaborating that there is shame and stigma associated with 
families having children with disabilities in their midst. Such children are more segregated in the Arab world as compared to the Western world, which is a proof that there have been improvements in the West earlier posited by Grames and Leverentz (2010). The research specifically focuses on a comparison between the East and the West because in comparison of the East or developing countries such as Saudi Arabia in particularly, the West has established important social, economic and health related measures and interventions to increase the social inclusion of the persons with disabilities and the measures taken by the countries such as the United Kingdom, European countries and the United States of America have also been effective in improving the status of the individuals with disabilities. Hence, the West serves as an important standard to compare the situation and status of the persons with disabilities and their perceptions toward the workplace and employers. Also, the West can be a role model to draw important recommendations to improve the status of people with disabilities. In Saudi Arabia, the current situation makes it difficult for people with disabilities to fully integrate into society. They are discouraged from being active members of society as they are not granted equal opportunities to join other people for purposes of personal and professional development. From the beginning, it can be noticed that the study emphasizes on a comparison between the UK and Saudi Arabia, and hence, no other countries are discussed. Moreover, in countries in Africa, Asia and the Middle East, the situation of and opportunities for the individuals with disabilities are mostly equivalent, hence it was not considered appropriate to compare Saudi Arabia with them

Nevertheless, there is hope that positive initiatives will be created to promote the well-being of people living with disabilities in Saudi Arabia. The focus has been on the creation of a workplace that limits discrimination against employees with disabilities. For instance, the Saudi Arabian Labor Law (Royal Decree No (D/51) dated 23/8/2006 amended) directly affects the status of workplaces by offering provisions on the role of employers in promoting equality in the workplace (Alfaraj \& Kuyini, 2014). In most cases, it is the role of all employers to ensure that employees with disabilities feel comfortable at work. According to Khoja (2016), the labor law might it be provided for employers to offer assistive technologies and facilities that will make it possible for the employees with disabilities to adapt to the workplace environment. For instance, employers are required to design facilities such as washrooms and other computer systems to ensure that people with disabilities can discharge their duties normally (Bolt, 2014). Further evidence indicates that employers are not supposed to engage in any form of discrimination against employees with disabilities in terms of promotion, training programs, wages, and access to career growth opportunities (Tideman \& Sevensson, 2015). All these legal directives target the role of employers and how their practice can be adjusted in such a way that the employees with disabilities do not feel any form of discrimination in the workplace. The segregation of individuals with disabilities is undeniable, which also brings into question segregation of jobseekers with disabilities. Previous studies have confirmed that there are elements of segregation against job-seekers by employers, which usually leads to discrimination during the hiring process (Blahovec, 2017). The findings of that research also reveal that $23 \%$ of the employers agree that stereotypes and perceptions are major barriers to recruitment of people with disabilities (Bendick, 2017). Bell (2019) suggests that interviews and on-site visits to several people with intellectual disabilities revealed that thousands of them have to spend majority of their time obtaining employment services in segregated sheltered workshops despite having the required capability and the desire to be employed. Alanazi (2018) emphasize that in Saudi Arabia, the people with intellectual disabilities encounter numerous issues during the vocational rehabilitation phase, including the post vocational rehabilitation phase and the job-hunting phase. The findings also highlight severe discrimination against the people with intellectual disabilities because of the neglect from the society and absence of adequate measures to make services and opportunities accessible to them (Alanazi, 2018). Another study by Mansour (2009) reveals that recruitment of people with intellectual disabilities does not form a part of the long-term plan of the employers in Saudi Arabia. A majority of the employers also avoid hiring people with intellectual disabilities because they believe that their presence would create negative impact on the customers (Mansour, 2009). These findings demonstrate what happens during the recruitment and employment process as it becomes more evident that jobseekers with disabilities are not considered suitable for employment and most employers tend to hire job seekers without any disabilities. This perception should be eliminated to ensure a fair platform of opportunity for all jobseekers, irrespective of their disability status.

The literature mentioned above begins with an extensive coverage of the history of segregation of people living with disabilities in Saudi Arabia as compared to the situation in the Western countries where policies have been developed to cater for their needs. The literature has also shown evidence for hope in the Saudi context, in the form of changes of culture toward accommodating people with disabilities at a younger stage. The literature has also shown that the government has been proactive in legislation intended to guide workplace behaviors in such a way to protect employees with disabilities from segregation (Alnahdi, 2018). The laws are aimed at promoting ethical behaviors among employers by ensuring that they create a comfortable workplace for all people 
including employees with disabilities. Employers are also barred from discriminating against employees with disabilities (Alajmi \& Albatal, 2016). However, despite the literature being inductive on these issues, there is no coverage of the rehabilitation programs that train people with disabilities in Saudi Arabia. This implies that the previous studies have not fully investigated the perceptions of adults with disabilities who are looking for jobs. Therefore, for the sake of research advancement, it is evident that there is a knowledge gap on this perspective, which the current research seeks to fill. In the light of the literature, the current research explored the experiences of intellectually individuals with disabilities in three stages: (a) people with intellectual disabilities and their training programs, (b) their jobs search experiences, and (c) the opinions of workers with intellectual disabilities about their work. Therefore, the following research questions were designed to guide the current research in solving the predetermined research problem.

1. What do individuals with intellectual disabilities think about the programs that prepare them in Saudi Arabia?

2. What are the procedures for employing adults with intellectual disabilities in Saudi Arabia?

3. What are the impressions of workers with intellectual disabilities about their work?

\section{Method}

A case study design was employed in this research as the researcher intends to describe a situation where it is necessary for evaluating a particular problem of interest. In all scenarios, case studies are considered necessary by researchers in order to answer research problems (Stake, 2013). The inclusion of a case study in this research was advantageous as it enabled the researcher to identify a specific issue that was consistent with a specific situation. In addition, case studies enable the researcher to capture complexities associated with real-life situations by aiding the process of solving complex problems (Swanborn, 2010; Thomas, 2017).

A typology for the case study selection was adopted from Thomas (2011) to enable the case selection and design planning process. The typology was necessary as there is a need to select more than one case to meet the goals of comparative analysis. The typology that was adopted in this study is presented in Figure 1.

\section{Figure 1}

Case Study Typology

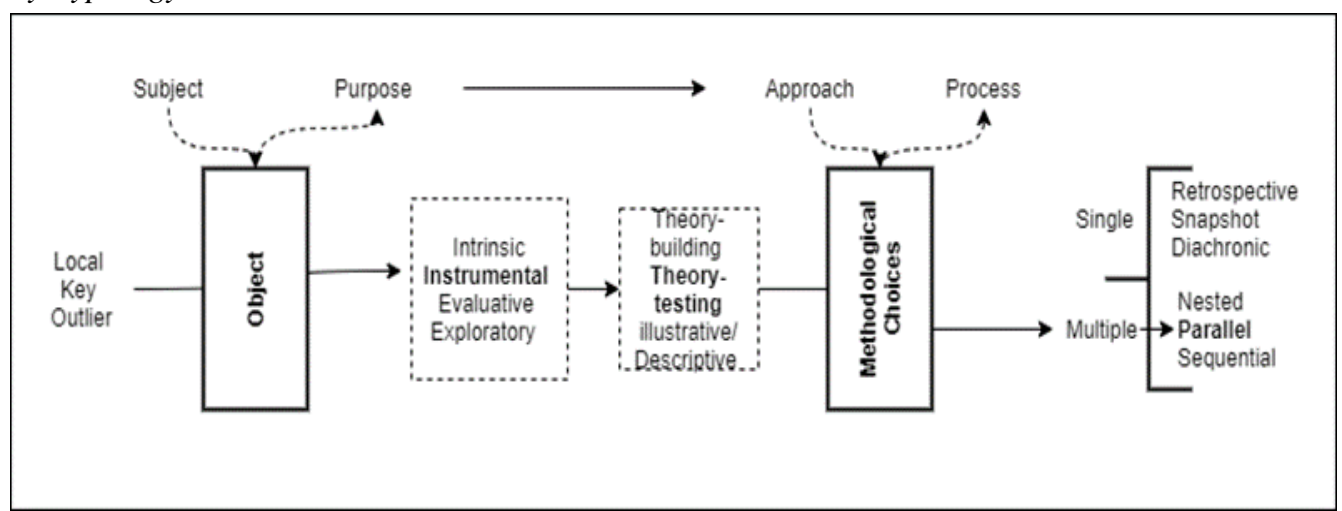

Note: This figure was adapted from "Thomas, G. (2011). A typology for the case study in social science following a review of definition, discourse, and structure. Qualitative Inquiry, 17(6), 511-521."

The case used in a case study is a subject of examination, which can be a class of phenomena that provides an analytical frame, also termed as an object within which the research is conducted. In this regard, a case study comprises of two elements: a practical component, termed the subject of the case study, and the analytical or theoretical frame, termed the object of the case study (Thomas, 2011). In the case of this research, the cases involve an examination and discussion of experiences of ten individuals with intellectual disabilities, classified into three groups. The first group included the individuals who had completed their vocational rehabilitation programs and were ready to work and the second group involved the individuals who were still seeking employment. The third group consisted of individuals who have work experience. The significance of classification in the case study is to gain clarity in identifying the expectations of these individuals, the purpose or goals to be achieved are, and the means of achieving them (Stake, 2005). Some authors classify a case study according to other factors such as the research questions, the level of analysis and the number of cases (Starman, 2013). In this context, Thomas (2011) 
states "As a typology in sense 'unrolls' the various considerations being made in the design of a case study, it perhaps implies that a series of separate design choices are made during the study planning" (Thomas, 2011, p. 518). The typology suggested by him is illustrated in Figure 1. A case study also presents a perspective for interpretation and contemplation, which exists within the process of research design. It encourages a precise articulation of the necessity and distinctness among the subject and the object. Moreover, a typology supports the consideration for illustrative and theoretical approaches, and decisions about the processes and methodological decisions (Thomas, 2011). The comparison of the cases for three groups in this research was undertaken with the help of this typology, thus serving as the means for assessing what the case studies were useful in addressing the objective of this research. The individuals experiencing various situations and people during the transition from study to work formed the critical subject of the case study. In this respect, the examination of the difficulties that they encountered while searching an employment, as well as the effectiveness of the training programs in the centers and exploration of their perceptions and experiences at the workplace formed the objective of the case study undertaken for this research. A case study approach was preferred in this study due to its ability to create distinctness among the different subjects under study and the research objectives under consideration. For this purpose, the typology above is important in making methodological decisions. The typology, hence, made it possible to undertake a realistic comparison between the three groups of the case studies in alignment with the intended objectives while executing them. The following sections present an outline of the application of the typology (Barela, 2007).

\section{Case Study Selection}

In this research, 10 cases were selected to determine the lived experiences of people with intellectual disabilities. In selecting those participants, help was obtained from the Ministry of Human Resources and Social Development in Riyadh that then made phone calls to the respective parents to explain them the context of the research. Regarding research ethics, especially interviewing people with intellectual disabilities, the researcher was very keen on complying with all legislations and protocols related to this procedure. The approval was made by the committee of Jouf University. According to Szucs et al., (2018) while interviewing an intellectually individuals with disabilities, it is of prime importance to avoid thinking that they cannot yield any useful information. To gain useful information from such individuals for research purposes, there are strategies which can be adopted. Language is the most important factor while communicating individuals with mild intellectual disabilities. As suggested by the results of several research studies, questions should be short. Use of double negatives and abstract concepts (why, if and how) should be omitted. Interviewer should first develop rapport and start conversation with general/casual questions. Individuals with mild and moderate disability levels often are taught to agree with other. In order to avoid this condition, use of exclamatory remarks should be avoided which otherwise will make them conscious and unconfident about their answer. It was suggested that in order to conduct better interviews it is important that the interviewers are professionals and have acquired with basic cognitive and experimental knowledge (Hollomotz, 2018; Lewis \& Porter, 2004; Tideman \& Sevensson, 2015).

In the initial stages, the Ministry contacted 18 families of individuals with intellectual disabilities 10 families of whom were selected based on their capabilities to take part in the study. Another consideration for their selection was based on their accessibility. For the purposes of maintaining the confidentiality and anonymity of the participants in this research the 10 participants were coded and divided into three groups to represent the three stages of the research questions. The reason for the division was the experiences of these individuals regarding to these questions. For the first question, 'What do individuals with intellectual disabilities think about the programs that prepare them in Saudi Arabia?', the participants will be referred to as A1, A2, A3, and A4. For the second question, 'What are the procedures for employing adults with intellectual disabilities in Saudi Arabia?', the participants will be referred to as B1, B2, and B3. Finally, for the third question, 'What are the impressions of workers with intellectual disabilities about the work?', the participants will be referred to as $\mathrm{C} 1, \mathrm{C} 2$, and $\mathrm{C} 3$. 
Table 1

Details of the Respondents

\begin{tabular}{|c|c|c|c|c|}
\hline Respondents & Male & Female & Age & Degree of intellectual disability \\
\hline Respondent A1 & & $\checkmark$ & 20 & Mild \\
\hline Respondent A2 & $\sqrt{ }$ & & 22 & Mild \\
\hline Respondent A3 & $\checkmark$ & & 21 & Mild \\
\hline Respondent A4 & $\checkmark$ & & 26 & Mild with physical disability \\
\hline Respondent B1 & $\sqrt{ }$ & & 22 & Mild \\
\hline Respondent B2 & $\checkmark$ & & 20 & Mild \\
\hline Respondent B3 & & $\checkmark$ & 25 & Mild \\
\hline Respondent C1 & & $\checkmark$ & 22 & Mild \\
\hline Respondent C2 & $\checkmark$ & & 21 & Mild \\
\hline Respondent C3 & $\sqrt{ }$ & & 23 & Mild \\
\hline
\end{tabular}

The participants were again classified so that the three research questions can be answered and their experiences during the training programs, the journey of searching for jobs and performing at the workplace can be studied clearly. The first stage focuses on question one and entailed an investigation with four participants referred to as A1, A2, A3 and A4. The participants were aged 20, 22, 21, and 26, respectively, and with intellectual disability (see Table 1). They reside in Riyadh, and their parents are employed. These participants were chosen to answer the first research questions because they have recently completed their professional rehabilitation programs, which makes them suitable for this question. The second case will be referred to as case B and it will be related to question 2. Three participants (B1, B2, and B3) were involved in responding to this question. All of them have intellectual disabilities and were aged 22, 20, and 25, respectively. All of them reside in Riyadh. The reason for choosing this respondent for this question is because these participants spent a period looking for work. In the third stage, participants will be referred to as case $\mathrm{C}$ and will respond to question 3 (see Table 2). They are three in total $(\mathrm{C} 1, \mathrm{C} 2$, and C3) and were aged 22, 21, and 23, respectively. They all live in Riyadh and employed, which makes them eligible for this part.

\section{Data Collection and Analysis}

10 semi-structured interviews were conducted with the ten participants on an individual basis. All the participants were interviewed at a vocational rehabilitation center or their respective workplace in Riyadh city after approval from the Ministry of Human Resources and Social Development was received. The process of interviewing the sample took two weeks and each interview lasted for about 30 to 40 minutes, wherein 37 interview questions were supposed to be answered by the respondents (see Appendix). The interview was conducted faceto-face with the respondents and was audio-video recorded, whose permission was already taken in the consent and the ethics form. Written transcripts were later created out of the audio recording and was used for coding and thematic analysis. The interview questions were developed by the author and were approved by two experts in the Special Education Department of the University of Jeddah and Jouf University.

\section{Validity}

Validity in context to research work is the aspect that confirms the authentication and truthfulness of outcomes by which the individuals would get influenced. Social validity is reflected as the satisfaction level as well as the acceptability of some procedures as well as resultant outcomes, which can be examined by the cognitive perspectives of individuals who verify and incorporate them. For confirming the validity of undertaken procedures along with the results of this research, fair and bias-free chance has been given to individuals suffering from intellectual disability and individuals without such disability to have a comparative understanding of their specific demands and needs in regard to workplace practices and environment.

Further, for confirming the social validity of interview questions used to produce the results, a questionnaire comprising 37 statements and 5-point scale measure (from 1 = Not at all; 2 = Poorly; $3=$ Somewhat; $4=$ Very much, to $5=$ Extremely) was used. The questionnaire tool submitted for testing the validity of interview 
questions for which $89 \%$ agreement was attained. In this way, social acceptance, as well as the significance of interview questions, could be verified. The questionnaire comprised of three essential dimensions, which are given as follows (Barret et al., 2001; Carter, 2010):

1. Essential questions regarding the significance of the aspects of support and training that are received by individuals with and without intellectual disabilities for developing rehabilitation abilities as well as capabilities to perform jobs in Saudi Arabian businesses (12 items).

2. Examination of participants for understanding their perception regarding interview questions concerned with issues of unemployment and challenges in finding jobs in Saudi Arabia due to disabilities (15 items).

3. Another vital agenda has been to examine the workplace environment's quality for individuals and the satisfaction level of them with employers and granted rights (10 items).

The aim of the interviews was to ask specific questions that would enable the study to collect the experiences of the participants in relation to work in Saudi Arabia. Comparative analysis was considered appropriate to investigate the differences and similarities among the findings from the participants.

\section{Thematical Analysis}

Thematic analysis was preferred in this study for purposes of generating themes designed to understand the research problem. To achieve this goal, Thomas' (2011) Typology was applied in the analysis of the three research questions, which also enabled the separation of subjects from objects. The analysis was also aimed at enhancing the understanding of how adults with intellectual disabilities in Saudi Arabia perceive the programs that prepare them for work, procedures for employing adults with intellectual disabilities, and impressions of workers with these disabilities about their work. Furthermore, the approach adopted in the analysis was highly oriented toward theory-testing by combining evidence from the literature review, and the responses from the interviews from the 10 participants. The diagram in Figure 2 is a representation of this process.

\section{Reliability}

For improving trustworthiness as well as reliability of outcomes of research, the accumulated data findings were reviewed by researchers who had worked with individuals having intellectual disabilities and who possess significant experience in handling qualitative data. In regard to the interview questionnaire, the researchers suggested eliminating three statements as well as amending four along with slight alterations of the remaining statements. In the interview questions' revision, 37 statements were finalized. Further, the two researchers were assigned as the coders (coder 1 as well as coder 2) to perform the coding process in regard to the work of data analysis. As per Miles and Huberman (1994), the technique of interrater reliability has an essential role in data coding. This technique has been conveyed to the research team for having significant insight into data patterns for generating codes. By considering the overall rating of two coders, the formula suggested by Miles and Huberman (1994) has been followed. It is noted that coder 1's agreement was 70\% in total, and disagreement of coder 1 was $30 \%$. Apart from this, coder 2's agreement was $8 \%$, while his disagreement was overall $15 \%$. After the calculation performed using the formula, the derived outcome was 0.775 . 


\section{Figure 2}

Case Study Plan

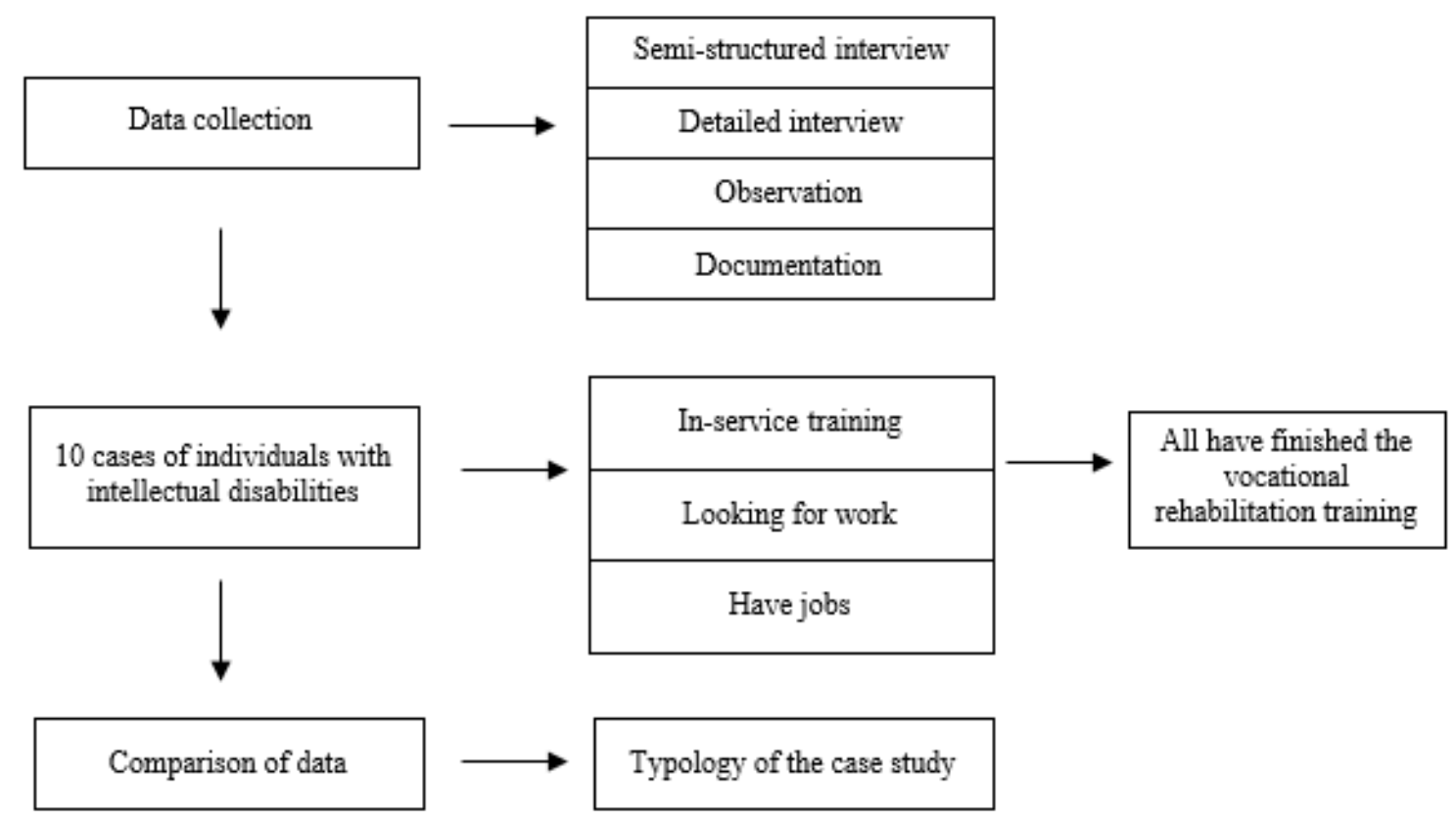

The outline of the Figure 2 is an illustration of the flow of the analysis process. It also shows the stages where the researcher made methodological choices. Themes were extracted from the interview responses. The following steps were followed in the analysis of the themes.

Table 2

Key Themes

\begin{tabular}{lc}
\hline \multicolumn{1}{c}{ Themes } & Research questions \\
\hline Inappropriate training, lack of equipment, unqualified specialists & RQ1 \\
Lack of trust, lack of awareness of rights, lack of opportunities & RQ2 \\
People's perceptions, low salary, lack of respect & RQ3 \\
\hline
\end{tabular}

\section{Step 1: Familiarization}

In this step, there was familiarization with the data through the process of closely examining the data and obtained in the form of the interview responses and the findings from the literature review. This step was necessary to evaluate the relevance of the findings and the manner in which they can be applied to responding to the research problem.

\section{Step 2: Code Generation}

This step was quite subjective in nature for purposes of making the identified code more relevant to the research objectives. The focus was to identify the codes that were closely associated with the areas of interest, which were the perception of the programs that prepared them for work, procedures for employing adults with intellectual disabilities, and impressions of workers with these disabilities about their work.

\section{Step 3: Theme Searching}

In this step, the different codes identified from the findings were clustered to generate specific themes. The theory on which the study was grounded was important in generating the desired theme. 


\section{Step 4: Theme Review}

This step involved having a closer look at the themes and sub-themes to ensure that they were relevant to the intended theory. The process was essential for the revising and adjustment of the themes to make them clearer. Alignment of the themes to the research question was also attained at this stage.

\section{Step 5: Theme Naming}

At this stage, themes were developed for purposes of thematic analysis.

\section{Step 6: Producing the Report}

This is the final stage where the researcher is expected to select detailed and comprehensive extracts as examples and associate them with the research questions and the linked literature, discussing them with the research question/s (Hilal \& Alabri, 2013). This process involved detailed discussion of the themes and is discussed in the findings of this research.

\section{Findings}

The research's focus was on how the participants perceived the programs that prepare them for work, procedures for employing adults with intellectual disabilities, and impressions of workers with these disabilities about their work in Saudi Arabia. The findings address the three research questions as follows.

\section{What do Individuals with Intellectual Disabilities Think about the Programs that Prepare Them in Saudi Arabia?}

This research question targeted four respondents that included A1, A2, A3, and A4. The purpose of the question was to determine the perception of the participants toward the programs targeting people with intellectual disabilities in Saudi Arabia. This question attracted mixed responses from the four participants. On this question, participant A1 stated that:

"More learning centers should be developed to help us easily find job opportunities because such centers act as a bridge that connects people with disabilities to employment. However, unlike in the United Arab Emirates, the rehabilitation centers in Saudi Arabia do not meet the standards of effective rehabilitation, which still complicates our situation."

The first response from A1 indicated that the Saudi environment does not provide enough support for individuals with intellectual disabilities. Hence, as a result, more of these people are more likely to face numerous challenges in preparedness for employment. A2 presented similar sentiments in relation to this question:

"A proper training for the people with disabilities is required for one to join the Saudi labor market, and this is achieved when one undergoes the training program in rehabilitation centers."

This response supports A1 as both participants agreed that the Saudi labor market is not concerned with advancing programs that promote the employability of people with intellectual disabilities. However, A3 had a different perspective toward this question:

"Websites have really helped me to apply for jobs in different companies as it is easy to contact other workers with disabilities for advice. My brother used websites to apply on my behalf for jobs which I was offered. I believe that it is an appropriate initiative becomes it makes work easy as it takes a short time and little effort, which is an advantage to us."

According to A3, there are websites that help new job applicants to apply for jobs in their respective companies. These websites make it easier for the applicants to apply for the jobs without having to physically present themselves at the company. Nevertheless, even though A3 believed that there has been some progress in ensuring that the people with intellectual disabilities are facilitated to apply for work, A4 added some suggestions that would improve the programs:

"The government should train everyone in Saudi Arabia to make them understand the rights of people living with disabilities. This will give them confidence in us and would eliminate the negative perceptions to us regarding our abilities to function in various capacities." 
A4 believed that the available programs are not achieving much in enhancing the employability of people with intellectual disabilities. Therefore, this means that the programs in Saudi Arabia are not as effective as they should be to meet the intended purpose.

\section{What are the Procedures for Employing Adults with Intellectual Disabilities in Saudi Arabia?}

This question was answered by participants B1, B2, and B3. On this question, one participant mentioned the issue of trust by the government and employers. Participant B1 stated that

"The government and employers do not have trust in us. They believe that we need more rehabilitation in vocational centers to boost our chances of employability. This is an issue that has negatively influenced our determination to apply for jobs and attend respective interviews, especially when we are already aware of the possible outcomes."

These observations indicate there is lack of definitive procedures focusing on the employability of people with intellectual disabilities apart from advanced skills. This is the reason why employers prefer job seekers with significant skills even though the programs in Saudi Arabia are not effective in achieving this outlined in the responses to question 1. This response was in tandem with B2's statement:

"The basic procedure is to apply for the job like the other jobseekers. And there is no consideration to promote the employability of the intellectually job seekers with disabilities because all of us are subjected to the same criteria. It is not fair."

In addition, B3 stated

"I find the procedures more punitive to people with intellectual disabilities. They always ask for skills and experience, which most of us don't have due to lack of opportunities. This is unfair competition."

Based on the responses to research question 2, it is evident that the procedures for employing adults with intellectual disabilities in Saudi Arabia do not favor them. People with disabilities believe that they are being treated like their counterparts without disabilities, which is problematic for them.

\section{What are the Impressions of Workers with Intellectual Disabilities about the Work?}

This question was responded to by $\mathrm{C} 1, \mathrm{C} 2$, and $\mathrm{C} 2$, who have been fortunate to be employed. The findings represent their personal perspective of the workplace environment as people living with intellectual disabilities. The responses are as follows.

Participant C1 was more concerned about the discrepancies existing in terms of the compensation they receive for the work done. This participant noted that people with disabilities are treated unequally in terms of salary:

"The salary is not sufficient for people living with disabilities as it is lower when compared with the money that the employees without disabilities are paid for the same jobs. I strongly believe that everyone in one job scale should be awarded the same salary as the rest of employees doing the same work."

Participant C2 was more concerned about the nature of the relationship between employees and management in the workplace:

"It is quite unfortunate that even senior managers in organizations are biased against us in interviews as they do not believe in our ability to perform our tasks like any other employee. In one of my interviews, the interviewers mainly asked my father and did not show any respect for my feelings and wishes." workplace:

Lastly, participant C3 presented sentiments similar to participant C2 demonstrating the relationship at the

"The work is okay, and I am capable of accomplishing my duties like any other persons when given the necessary help. However, the manager and co-workers always show too much empathy and lack of trust in us as they are not sure whether we can perform the tasks in the manner required. This is quite demoralizing for most of us." 


\section{Discussion}

The purpose of this study is to examine the opinions of the people with intellectual disabilities regarding the vocational programs in Saudi Arabia, the procedure used to employ adults with intellectual disabilities and the impression of workers with such disabilities regarding their work. The findings obtained from the interview with 10 individuals in Saudi Arabia revealed that the respondents tend to encounter numerous challenges at the workplace. These difficulties include access to limited skills development, lack of trust from employers, perceptions of low skills and low salaries, and perception of being incapable of performing a job responsibility. The findings also highlight that the people with intellectual disabilities feel that there is a need to sensitize the society regarding the rights of those people, require employers to implement disability programs and develop websites to facilitate job-search, rehabilitation, and training centers.

In the context of these findings, it can be discussed that a majority of the participants agreed that the programs that prepare people with intellectual disabilities in Saudi Arabia are ineffective. Based on their experiences, the participants believed that the government has a lot of work to do in ensuring that the existing programs are strengthened, and others put in place to enhance the comfort of people with intellectual disabilities. The failure of these programs means that the employers might fail to enhance their competence in promoting equity at the workplace. Their perceptions toward people living with intellectual disabilities is also a problem. The participants stated that there was a lack of trust and instances of discrimination from the side of employers. According to the literature, people's behaviors toward disability influenced their perceptions of the people with disabilities (Hannon, 2017). Heera and Devi (2016) confirm that the employers have a firm perception that the people with intellectual disabilities have a lower potential to be employed and they are unable to integrate and participate fully at the workplace. The study also emphasizes that employers believe that people with such disabilities are in a more disadvantageous position than those with other kinds of disabilities (Heera \& Devi, 2016). People with visual or physical disabilities tend to receive relatively positive reactions from the employer during the recruitment process in comparison to the ones experiencing intellectual disabilities (Heera \& Devi, 2016). Kadi (2018) further reveals that stigmatization, stereotyping, discrimination, and prejudice are significant attitudinal barriers imposed on the people with intellectual disabilities and create a highly significant negative impact on them. Perception of rejecting people with disabilities is a shared and common feeling between groups of people who believe in rejecting people with disabilities because of intellectual limitations. In this context, Mansour (2009) state that the majority of the organizations in Saudi Arabia do not consider employing persons with disabilities and do not even have policies for them. Most organizations also have negative perceptions regarding the employment of persons with disabilities and low rates of recruitment, which also indicates that the perceptions of employers are shaped by the cultural ideologies of the people toward the persons with disabilities in society (Mansour, 2009). Alkhouli (2015) further elaborate on these findings and reveal that the persons with disabilities, even when employed, are not considered for the managerial or executive position because of their functional impairments and the stereotypes developed against them. Most people with disabilities working in the organizations are employed at positions requiring no specific skills. These tendencies of the employers are shaped by their prejudices regarding the lower expectations from the persons with disabilities and believe them to be risky, inferior and undesirable for the organization (Alkhouli, 2015).

Such social attacks against the people with disability have the potential of causing severe damage to their dignity and forcing them to live in a life dictated by stereotypes and denied of respect and right of choosing their living (Kadi, 2018). These findings suggest that the culture of discrimination against people with disability in Saudi Arabia is based on subjective perceptions of the people rather than any rational causes. Workplace procedures are also impactful on the employability of people with intellectual disabilities in Saudi Arabia. For instance, it has been established in the literature that several changes usually take place in workplaces that make it problematic for people with disabilities to perform their tasks as required by employers (Chen et al., 2014). Wilson and Scior (2015) argue that the demeaning and hostile tendencies toward people with disabilities when they are treated as inferior and undesirable permeate in the society and serves as an important cause of the hate crimes against people with disabilities. Hostile and contemptuous perceptions for a long duration also tends to create a highly negative environment for them (Wilson \& Scior, 2015).

Hence, for this reason, people with disabilities find it difficult to adopt to the workplace with the desired efficiency in addition to limiting their chances of growth and development of skills in their respective workplaces (El-Hady, 2011; Grames \& Leverentz, 2010). For this reason, it mainly depends on what the employer believes with regard to whether the employee with disabilities will be either a liability or an asset to the company. 
Accordingly, procedures focus mainly on the skills of the job seekers, even when they know that their capacity is limited as compared to the employees without disabilities.

There are many reasons that can explain why such occurrences take place in organizations. The literature details that employers usually find it problematic to hire employees with disabilities and would rather pay them even when not working for fear that people with disabilities might fail the performance test during the interviews (Alnahdi, 2018). Another reason for such an occurrence is that employers fear taking care of employees with disabilities in accordance with the disability laws that the government has established to guide workplaces where individuals with disabilities work (El-Hady, 2011; Grames \& Leverentz, 2010). For instance, the Saudi Arabian Labor Law (2006) directly affects the status of workplaces by offering provisions on the role of employers in promoting equality in the workplace (Mansour, 2009). Another finding from the interviews is that some of the participants believed that the low salary offered to them as compared to the salary paid to the employees without disabilities was further evidence of negative perceptions that employers have to them. According to the literature, the low salary is one of the aspects of discrimination against the employees with disabilities alongside other practices such as promotion, training programs, and access to career growth opportunities (Mansour, 2009). This type of discrimination therefore affects many employees with disabilities in Saudi Arabia. The implication is that the role of employers and their practices could be adjusted in such a way that the employees with disabilities do not feel any form of discrimination in the workplace. This is also what the disability laws are attempting to achieve in Saudi Arabia but still yet to show proof of success. The findings of the interviews also offer recommendations that the participants believed would help to solve the challenges. The first solution is that social perceptions could be transformed by creating awareness among the population to advance their understanding of the rights of people with disabilities. Similarly, the interviews found that the government should train everyone in Saudi Arabia to enable them to understand the rights of people living with disabilities. According to the findings, such approaches would increase confidence in individuals with disabilities and eventually eliminate negative perceptions regarding their ability to function in various capacities. In this context, Thompson et al. (2012) highlights that explicit attention can be paid to the people with severe intellectual disability, reinforcing consistency in supervision, pre-and in-service training and formal functional procedures of organizations, lay down the policies in published formats so that maximum knowledge and awareness can be spread among the members of the organization. The literature also explains that there must be regular and individualized supervision to support the staff members to understand the values toward persons with disabilities and generate performance expectations and ensure that their needs are effectively addressed (Thompson et al., 2012). However, this process might take longer since it involves cultural change in Saudi society regarding disability.

\section{Conclusion, Limitations and Suggestions}

This research aims at exploring the difficulties experienced by young people with intellectual disabilities while transitioning from school to work and evaluate their perceptions toward the workplace and programs that prepare them in Saudi Arabia. The data to address this aim of the research has been discussed through a case study developed with the help of observations, semi-structured interviews, and documentation to answer the research questions. From the examination and analysis of the research findings, it can be concluded that there are several relevant issues experienced by people with intellectual disabilities that create serious issues while undertaking transition from school to work. These issues include lack of trust, inappropriate training, lack of adequate employment opportunities, low salary, stereotypical perceptions of the people and lack of respect. Based on these research findings, it is proposed that the government of Saudi Arabia must develop planned goals and objectives that can help in training and guiding people with intellectual disabilities. Moreover, the development of such measures and policies must not only be restricted to the government, but also be undertaken by the industries and organizations such that the awareness regarding the persons with disabilities can be increased and more suitable job positions can be created for them. One of the important reasons for the critical issues encountered by the people with disabilities during transition to work is the negative perception of the people toward people with disabilities. In this context, the government of Saudi Arabia can also be recommended to develop and create specific policies that are focused on the promotion of social inclusion in the schools and workplaces.

Additionally, further research can also be conducted on the measures that can be adopted by organizations to promote their employment and facilitate and support their career growth and development in an effective manner. Future research can also be conducted on the measures and interventions undertaken by the government and organizations in the developed countries and the findings of such research can be implemented to improve the well-being of the people with disabilities in Saudi Arabia. Additionally, further research can focus on the role of 
Information and Communication Technology (ICT) for the skills development and personal development of people with intellectual disabilities.

The main strength of the research is that it covers an area that has previously attracted limited research, especially when viewed from the perspective of Saudi Arabia. The other strength is methodological as the adoption of the interview approach made it possible for the researcher to collect in-depth findings from the participants in the form of lived experiences, which then facilitates understanding the phenomenon. Therefore, the adoption of the interview approach enabled a deeper understanding of the research problem from the perspective of primary data sources, which were the three cases. However, the study presents some methodological limitations. First, the study applied only a qualitative approach in form of interviews, which led to the collection of subjective data. Furthermore, in this research only 10 participants were interviewed which limits the generalizability of the findings. Hence, in the future, researchers should consider using quantitative approaches and collect data from a larger sample size to enhance the generalizability of the findings.

The findings of the study outline an understanding of the situation of disability in Saudi Arabia and explain the challenges that the employees with disabilities and job-seekers face as a result of the perceptions of other people toward them. Hence, with reference to the results, policy makers in Saudi Arabia could design essential policies that would improve the well-being of people living with disability by triggering a societal culture change that promotes positive perceptions to people with disabilities. The same point also applies to employers as they will now have a better understanding of the situation, and they are more likely to improve their workplaces to accommodate the employees and jobseekers with disabilities.

It is also recommended that the government and the organizations of Saudi Arabia must implement the social model to develop most appropriate ideas, policies and laws that can offer maximum benefit to address the employment needs of the persons with disabilities. The application of the social model will help in eliminating the barriers and promoting the measures developed to help address the needs and issues of persons with disabilities (Alkhouli, 2015). It would also serve as a suitable strategy to transform the perceptions and conceptions regarding disability. This model can also serve to be more effective than a medical intervention or rehabilitation strategy. The social model also offers a useful framework to transform the perceptions of the people and thus can help empower the people with disabilities at the workplaces (Yousef, 2018).

It was recommended that the government introduce a range of labor laws and regulations that encourage organizations to hire and retain persons with disabilities. These laws will increase awareness and responsibility among the employers, which will promote behavioral change. Such awareness can be targeted at ensuring that persons with disabilities are hired and offered effective training. An increase in the level of awareness and knowledge regarding disability can play an essential role in bringing a significant change in society toward persons with disabilities (Alkhouli, 2015).

\section{Acknowledgment}

The author extends his appreciation to the Deanship of the Scientific Research at Jouf University for funding this work through research grant (No. DSR-2021-04-0216).

\section{Funding}

The research reported here was supported by the Deanship of Scientific Research, Jouf University. 


\section{References}

Aiden, H., \& McCarthy, A. (2014). Current attitudes towards disabled people. https://researchinformation.bris.ac.uk/ws/portalfiles/portal/88783477/Aiden_and_McCarthy_2014.pdf

Alajmi, N., \& Albatal, J. (2016). The most important difficulties that face the employment of persons with intellectual disability from the perspective of workers in the intellectual education institutes and programs in Riyadh. Journal of Al-Quds Open University for Educational \& Psychological Research \& Studies, 4(14), 237-270. https://digitalcommons.aaru.edu.jo/jaqou_edpsych/vol4/iss14/7

Alanazi, A. (2018). The difficulties witnessed by people with intellectual disability in transition to work in Saudi Arabia. International Journal of Educational and Pedagogical Sciences, 12(4), 521-530. https://doi.org/10.5281/zenodo.1316480

Alfaraj, A., \& Kuyini, A. (2014). The use of technology to support the learning of children with down syndrome in Saudi Arabia. World Journal of Education, 4(6), 42-53. https://doi.org/10.5430/wje.v4n6p42

Algahtani, G. (2017, February 8). Challenges toward the preparation of special needs students in high schools to their post- school, work and their independent lives [Paper presentation]. Future Vision on Special Education Conference,

Al-Sharjah-UAE. https://www.sharjah.ac.ae/en/Media/Conferences/Pages/default.aspx

Alkhouli, D. (2015). Employment policy for people with disabilities in Saudi Arabia [Doctoral dissertation, Manchester Metropolitan University]. https://e-space.mmu.ac.uk/898/1/thesis\%2009977705.pdf

Alnahdi, G. (2018). Special education teacher transition-related competencies and preparation in Saudi Arabia. International Journal of Special Education, 29(2), 59-67. https://files.eric.ed.gov/fulltext/EJ1029006.pdf

Barela, E. (2007). Book review: Multiple case study analysis, by Robert E. Stake. New York: Guilford Press, 2006. American Journal of Evaluation, 28(4), 570-572. https://doi.org/10.1177/1098214007307454

Bell, M. (2019). People with intellectual disabilities and employment discrimination law: A US case study. International Journal of Comparative Labour Law and Industrial Relations. https://www.researchgate.net/publication/332470416_People_with_Intellectual_Disabilities_and_Empl oyment_Discrimination_Law_a_US_Case_Study

Bendick, M. (2017). Employment discrimination against persons with disabilities: Evidence from matched pair testing. https://www.researchgate.net/publication/316628595_Employment_Discrimination_Against Persons_with_Disabilities_Evidence_from_Matched_Pair_Testing

Blahovec, S. (2017). Why hire disabled workers? 4 powerful (and inclusive) companies answer. https://www.huffingtonpost.com/sarah-blahovec/why-hire-disabledworkers_b_9292912.html

Bolt, D. (2014). Changing social attitudes toward disability. Routledge.

Carter, S. L. (2010). The social validity manual. A Guide to subjective evaluation of behavior interventions. Academic Press.

Chen, J., Leader, G., Sung, C., \& Leahy, M. (2014). Trends in employment for individuals with autism spectrum disorder: A review of the research literature. Review Journal of Autism and Developmental Disorders, 2(2), 115-127. https://doi.org/10.1007/s40489-014-0041-6

Cubbage, J. (2017). How will they learn without access? Ending the exclusion of disabled students. Journal of Media and Literacy Education, 9(2), 114-121. https://doi.org/10.23860/JMLE-2019-09-02-09

Dare, L., Nowicki, E., \& Felimban, H. (2018). Saudi children's thoughts on inclusive education. International Journal of Inclusive Education, 21(5), 532-543. https://doi.org/10.1080/13603116.2016.1218948

El-Hady, Z. (2011). Attitudes to disability: Islam, the West and the Middle East. http://www.commentmideast.com/2011/10/attitudes-disability-islam-west-middle-east/.

Grames, M., \& Leverentz, C. (2010). Attitudes toward persons with disabilities: A comparison of Chinese and American students. Journal of Undergraduate Research, 1, 1-6. https://doi.org/10.1007/s12144-014$\underline{9253-2}$ 
Hannon, F. (2017). Literature review on attitudes toward disability (Disability Research Series No. 9). National Disability Authority.

Heera, S., \& Devi, A. (2016). Employer's perspective toward people with disabilities. The South East Journal of Management, 10(1), 54-74. https://doi.org/10.21002/seam.v10i1.5960

Hollomotz, A. (2018). Successful interviews with people with intellectual disability. Qualitative Research, 18(2), 153-170. https://doi.org/10.1177/1468794117713810

Hilal, H., \& Al Abri, S. (2013). Using NVivo for data analysis in qualitative research. International $\begin{array}{lllll}\text { Interdisciplinary Journal } & \text { 181-186. }\end{array}$ http://www.iijoe.org/v2/IIJOE_06_02_02_2013.pdf

Kadi, S. A. (2018). Why does Saudi Arabia have fewer leaders with disabilities? Changing perspectives and creating new opportunities for the physically challenged in Saudi Arabia (Publication No. 10784556) [Doctoral dissertation, Pepperdine University]. ProQuest Dissertations and Theses Global. https://www.proquest.com/dissertations-theses/why-does-saudi-arabia-have-fewer-leaderswith/docview/2033023911/se-2

Khoja, S. (2016, February 3). KSA: An employer's duty to facilitate the employment of disabled employees. Aljazira Newspaper. https://s3.amazonaws.com/documents.lexology.com/93b80f7f-3dca-4b60-91bde6568456e2c0.pdf?AWSAccessKeyId=AKIAVYILUYJ754JTDY6T\&Expires=1647459941\&Signature =p9Tfw2O\%2FISDcRmU\%2FIKNTZkBY74w\%3D

Lewis, A., \& Porter, J. (2004). Interviewing children and young people with learning disabilities: Guidelines for researchers and multi-professional practice. British Journal of Learning Disabilities, 32(4), 191-197. https://www.researchgate.net/profile/A-Biba-Rebolj2/publication/265682891_The case_study as a type of qualitative research/links/54183f560cf25ebee988104c/The-case-study-as-a-type-ofqualitative-research.pdf

Mackelprang, R., \& Salsgiver, R. (2015). Disability: A diversity model approach in human service practice (3rd ed.). Lyceum.

Mansour, M. (2009). Employers' attitudes and concerns about the employment of disabled people. International Review of Business Research Papers, 5(4), 209-218. https://doi.org/10.1177/108835760201700101

Miles, M., \& Huberman, M. (1994). An expanded sourcebook qualitative data analysis. Sage Publication.

Stake, R. M. (2005). Qualitative case studies. In N. Denzin \& Y. Lincoln (Eds.), The SAGE handbook of qualitative research (3rd ed., pp. 443-466). Sage.

Starman, A. (2013). The case study as a type of qualitative research. Journal of Contemporary Educational Studies, 1(2), 28-43. https://doi.org/10.1016/S0140-6736(01)05627-6

Swanborn, P. (2010). Case study research: What, why and how? SAGE.

Szucs, A., Schau, C., Muscara, K., \& Tomasulo, D. (2018). Character strength activation for people with intellectual and developmental disabilities using video feedback in groups. Journal of Education and Learning, 8(1), 12-20. https://doi.org/10.5539/jel.v8n1p12

Thomas, G. (2011). A typology for the case study in social science following a review of definition, discourse, and structure. Qualitative Inquiry, 17(6), 511-521. https://doi.org/10.1177/1077800411409884

Thomas, G. (2017). How to do your research project: A guide for students in education and applied social sciences. SAGE.

Thompson, D., Fisher, K. R., Purcal, C., Deeming, C., \& Sawrikar, P. (2011). Community attitudes to people with disability: Scoping project. Department of Families, Housing, Community Services and Indigenous Affairs. https://dx.doi.org/10.2139/ssrn.2014423

Tideman, M., \& Sevensson, O. (2015). Young people with intellectual disability- The role of self-advocacy in a transformed Swedish welfare system. International Journal of Qualitative Studies in Health and WellBeing, 10(1), 1-8. https://doi.org/10.3402/qhw.v10.25100 
Unite for Sight. (2016). Cultural perspectives on mental health. http://www.uniteforsight.org/mentalhealth/module7

Yousef, R. (2018). Disability, social work and social exclusion: New strategies for achieving social inclusion of people with physical disabilities in the Kingdom of Saudi Arabia [Unpublished doctoral dissertation]. University of Salford Manchester.

Wilson, M. C., \& Scior, K. (2015). Implicit attitudes toward people with intellectual disabilities: Their relationship with explicit attitudes, social distance, emotions and contact. PLoS ONE Journal, 10(9) 1-19. https://doi.org/10.1371/journal.pone.0137902 


\section{Appendix \\ Interviews Questions}

\section{Questions related to training programs}

1. In which activities are you good?

2. How did you know to do that?

3. What are your future goals and dreams?

4. What are the difficulties that you faced while you are training in the center?

5. So, in this centre, did you have any training program related to work in vocational rehabilitation centre?

6. What do you think about the good training programs in Saudi centres?

7. Did these training programs in vocational center assist you to prepare to your next level after school?

8. What type of training/classes did you have to make you choose what do you want?

9. Do you think time that you spent on training programs was sufficient?

10. What do you think about the good training programs in these centers?

11. What do you suggest making your transition to work easier?

12. Do you think that there is a relationship between the training programs in rehabilitation centers and work?

\section{Question related to unemployment}

1. Who is responsible about your unemployment?

2. Do you think your high school/ vocational centre teachers/specialists trained you some effective skills related to work experience?

3. Where do you like to work in government or private sector?

4. Why? Did you apply for any work?

5. When do you find a work, do you think you will be useful for the community, How?

6. Do you think that you can work there for a long time?

7. Do you like to work near your house?

8. What about internet Website, did you try to apply for jobs on these Websites?

9. What are the difficulties that you faced while you are looking for a job?

10. What about your friends in the rehabilitation centre, do you think that they found work?

11. Why?

12. Why did not you apply for these works?

13. What do you suggest making your transition to work easier?

14. Where do you like to work in the government or the private sector?

15. Do you think assistive technology such as searching on the Website helped you?

Questions related to the attitudes of the work

1. Did you find work during the three months after you finished your training programs?

2. Why? Did you apply for any work?

3. Did you make the interviews for these jobs?

4. What you think about these interviews?

5. How did you know about these jobs? 
6. What you think about your co-workers, do you like to work with them?

7. Do like to work in other activities?

8. If you had trained properly on other activities you might like to do, and you find a job in these activities, you will quit this job?

9. So, I hope after four months you will open your coffee truck, did you choose the place?

10. What you think about the community, are they friendly intellectually disabled people? 


\section{Ankara Üniversitesi Eğitim Bilimleri Fakültesi Özel Eğitim Dergisi}

2022, 23(2), 295-317
ARAŞTIRMA

Gönderim Tarihi: 03.08.20

Kabul Tarihi: 11.05 .21

Erken Görünüm: 24.08.21

\title{
Zihinsel Engellilerin İşyeri Ortamı ve Uygulamalarına Yönelik Algıları
}

\author{
Adel Alanazi iD 1
}

$\ddot{\mathbf{O} z}$

Giriş: Suudi Arabistan'da zihinsel engelli kişilerle ilgili alanyazın incelendiğinde, bu bireylerin gereksinimlerine yönelik geliştirilen politikalar, engellilere uyum sağlamak için Suudi kültüründeki değişiklikler, hükümetin işverenlerin işyerindeki ayrımcılıkları engellemek için politikaları yönlendirmede aldığı önleyici tedbirler hakkında önemli bulgular ortaya koymaktadır. Bununla birlikte, Suudi Arabistan'da engellilikle ilgili bu hususlar üzerine yapılan kapsamlı araştırmalara rağmen, iş arayan engelli yetişkinlerin algılarına ilişkin herhangi bir çalışma bulunmamaktadır. Suudi Arabistan'da engellilerin eğitimine yönelik rehabilitasyon programlarının akademik alanyazındaki kapsamı oldukça sınırlıdır. Mevcut alanyazında önemli bir boşluk olarak tespit edilen Suudi Arabistan'daki zihinsel engelli bireylerin deneyimlerini araştırmaya ihtiyaç olduğu belirlenmiştir. Bu bağlamda bu çalışmanın amacı, Suudi Arabistan'daki 10 zihinsel engelli kişinin işyeri ortamı ve uygulamalara yönelik algılarını belirlemektir.

Yöntem: Katılımcılar Riyad İnsan Kaynakları ve Sosyal Kalkınma Bakanlığı'nın yardımıyla seçilmiştir. Katılımcıların üçü erkek, gerisi kadındır. Katılımcılar 20-26 yaşları arasındadır ve hafif düzeyde yetersizlikleri mevcuttur. Araştırmanın verileri, derinlemesine görüşmeler yoluyla toplanmış ve ardından tematik olarak analiz edilmiştir.

Bulgular: Bulgular, katılımcıların mesleki beceri gereksinimlerini ortaya koymuş, işverenlere yönelik güven eksikliği duyduklarını, gerektiği gibi çalışamadıklarını, mesleki becerilerini yetersiz gördükleri ve maaşlarının düşük olduklarını belirterek işe alım zorlukları yaşadıklarını göstermektedir. Katılımcılar ayrıca toplumun engellilerin haklarına duyarlı hale getirilmesi, işverenlerin engelli programları uygulamaya mecbur bırakılması, iş aramayı artırmak için web siteleri geliştirilmesi ve rehabilitasyon ve eğitim merkezlerinin güçlendirilmesi gerektiğini belirtmişlerdir.

Tartışma: Örgütlerde bu tür olayların yaşanmasını açıklayabilecek pek çok neden vardır. Literatür, işverenlerin genellikle engelli çalışanları işe almayı sorunlu bulduklarını ve görüşmeler sırasında engelli kişilerin performans testinde başarısız olabileceği korkusuyla çalışmıyor olsalar bile onlara ödeme yapmayı tercih ettiklerini detaylandırmaktadır.

Sonuç: Hükümet ve işverenler, Suudi Arabistan'da iş arayan ve çalışan engellilerin refahını iyileştirmeye yönelik politikalar oluştururken bu bulguları göz önünde bulundurmalıdır.

Anahtar sözcükler: Algılar, işe ilişkin algılar, zihinsel engelliler, işyeri ortamı, uygulamalar.

Atıf için: Alanazi, A. (2022). Zihinsel engellilerin işyeri ortamı ve uygulamalarına yönelik algıları. Ankara Üniversitesi Eğitim Bilimleri Fakültesi Özel Ĕgitim Dergisi, 23(2), 295-317. https://doi.org/10.21565/ozelegitimdergisi.776646

\footnotetext{
${ }^{1}$ Sorumlu Yazar: Dr. Öğr. Üyesi, Jouf Üniversitesi, E-posta: asalanazi@ju.edu.sa, https://orcid.org/0000-0002-6378-1073
} 


\section{Giriş}

$\mathrm{Bu}$ araştırma, Suudi Arabistan'da zihinsel engelli gençlerin okuldan işe geçişte yaşadıkları zorlukları araştırmayı ve işyerine yönelik algılarını ve onları hazırlayan programları değerlendirmeyi amaçlamaktadır. Suudi Arabistan'daki engelli insanlar, sosyal bütünleştirmenin önündeki çeşitli kültürel ve toplumsal engellerle karşılaşmaya devam etmektedir (Yousef, 2018). Krallık'ta engelli kişilere yönelik ciddi bir ihmal gözlemlenmiştir. Bu da hükümetin engelli kişilerin yaşam kalitesini iyileştirmek için aldığı sınırlı önlemlere atfedilebilir. Ayrıca, Krallık'ta engelli kişilere yardım ve rehberlik etmek için güvenilir bir hükümet yardım hattı veya engelli kişilerin haklarını ortaya koyan kamuya açık bir yasal düzenleme bulunmamaktadır. Bununla birlikte onlara mali veya sosyal destek hizmetleri sunmak için herhangi bir merkezi veya resmi kayıt da bulunmamaktadır (Yousef, 2018). Suudi Arabistan'da engellileri kapsayacak yeterli yasaların olmadığı da belirlenmiştir. Suudi işverenlerin istihdam edilen engelli kişilerin çıkarlarını güvence altına almasına yönelik ulusal ayrımcılık karşıtı yasalar bulunmamaktadır (Mansour, 2009). Yasaların bu eksikliği, istihdam edilmek isteyen engellilerin seslerini daha da bastırmaktadır. Buna ek olarak, Suudi Arabistan'daki engellilik ile ilgili çalışmalar esas alınarak engelli kişilerin toplumdaki rehabilitasyon ve tedavisi üzerine yoğunlaşan mevcut alanyazın da incelenmiştir. Engelli insanlar için istihdam politikası konusunda herhangi bir araştırma bulunmamaktadır (Alkhouli, 2015). Krallıktaki engellilik sorunu, ülkenin politika yapıcıları için önemli bir endişe kaynağıdır. Burada, ekonomik bağımsızlık aramak için önemli bir potansiyele sahip olan ve yetersizlikten etkilenen nüfusun yaklaşık \%3.73'ü bağımlı olmaya devam etmektedir (Alkhouli, 2015). Bu bulgular, Suudi Arabistan'da engellilik sorununun ciddiyetinin ve bu tür engelli kişilerin algılarının incelenebileceği konusunun yanında, işyerlerinde yeterli istihdam olanaklarının sağlanması ve işyerlerinde sosyal bütünleştirmenin sağlanmasına yardımcı olacak uygun çözümlerin araştırıldığı önemli araştırmalara duyulan ihtiyacı daha da vurgulamaktadır.

Dahası, mevcut araştırma Suudi perspektifini ele aldığından, Suudi toplumunun Krallıktaki engellilik durumu üzerindeki kültürel etkisini değerlendirmek de aynı derecede önemlidir. Grames \& Leverentz (2010) çalışmalarında, Batı ülkelerinin politika geliştirme yoluyla engellilerin refahında olumlu gelişmeler yaratmaya çalıştıklarını, Arap ülkelerinin çoğunun ise engelli bireylere karşı etiketlemeyi kontrol edememeleri nedeniyle hala geride kaldıklarını savunmuşlardır. Buna ek olarak, Arap ülkelerinde engelli insanlar için sosyal bir bakım modeli toplumun tutumları nedeniyle henüz geliştirilememiştir (Alajmi \& Al-Batal, 2016). Son zamanlarda alanyazında engelli çocukları olan ailelerin bu durumdan utandıkları ve toplumda kendilerine ilişkin olumsuz etiketlemeler olduğu vurgulanmaktadır (Hannon, 2017). Bu tür çocuklar Arap dünyasında Batı dünyasına kıyasla daha fazla ayrıştırılmaktadır. Bu da daha önce Grames ve Leverentz (2010) tarafından belirtildiği gibi Batı'da iyileştirmeler olduğunun kanıtıdır. Araştırma özellikle Doğu ve Batı arasında bir karşılaştırma üzerinde durmaktadır çünkü özellikle Suudi Arabistan gibi Doğu veya gelişmekte olan ülkeler ile karşılaştırıldığında Batı, engelli kişilerin sosyal bütünleştirmesini artırmak için önemli sosyal, ekonomik ve sağlık ile ilgili önlemler almış ve müdahaleler gerçekleştirmiştir. İngiltere gibi ülkeler tarafından alınan önlemler, Avrupa ülkeleri ve ABD'de engellilerin durumunun iyileştirilmesinde etkili olmuştur (Aiden \& McCarthy, 2014). Dolayısıyla Batı, engelli kişilerin durumu ve statüsü ile işyeri ve işverene yönelik algılarını karşılaştırmak için önemli bir standart olarak hizmet etmektedir. Ayrıca, Batı ülkeleri, Suudi Arabistan'da engellilerin durumunu iyileştirmek üzere önemli öneriler vermek için istekli olabilir. Baştan beri, çalışmanın Birleşik Krallık ile Suudi Arabistan arasında bir karşılaştırmaya vurgu yaptığı ve dolayısıyla başka hiçbir ülkenin tartışılmadığı görülebilmektedir. Ayrıca Afrika, Asya ve Orta Doğu ülkelerinde engellilerin durumu ve firsatları çoğunlukla eşdeğer olduğundan, Suudi Arabistan'ı onlarla karşılaştırmak uygun görülmemiştir. Engelli insanların topluma tam olarak entegre olmalarının zorlaşması bu bireylerin engelli olmayanların yararlanabileceği faaliyetlere aktif katılımlarını sınırlamaktadır. Engelli insanlara kişisel ve mesleki gelişimlerini desteklemek amacıyla diğer insanlara katılmaları için eşit firsatlar tanınmadığından, bu kişiler toplumun aktif üyeleri olamamaktadırlar. Alanyazın ayrıca hükümetin, işyerlerindeki davranışları engelli çalışanları ayrımcılığa karşı koruyacak şekilde yönlendirmeyi amaçlayan mevzuatta proaktif olduğunu göstermiştir (Alnahdi, 2018). Yasalar, engelli çalışanlar da dâhil olmak üzere tüm bireyler için rahat bir işyeri oluşturmayı sağlayarak işverenler arasında etik davranışları teşvik etmeyi amaçlamaktadır. İşverenlerin engelli çalışanlara karşı ayrımcılık yapmaları da yasaklanmıştır (Alajmi \& Albatal, 2016). Bununla birlikte, alanyazın bu konularda tümevarımsal bir yaklaşım izlemekle birlikte Suudi Arabistan'da engellileri eğitecek kapsamda rehabilitasyon programları yer almamaktadır. Bu nedenle, alanyazındaki çalışmalarda iş arayan engelli yetişkinlerin algıları tam olarak ele alınmadığı düşünülmektedir. $\mathrm{Bu}$ nedenle, mevcut araştırmanın bu perspektifteki bilgi boşluğunu dolduracağı öngörülmüştür. Alanyazın ışığında, mevcut araştırma zihinsel engelli bireylerin deneyimlerini; zihinsel engelli bireyler ve eğitim programları, zihinsel engelli bireylerin iş arama deneyimleri ve zihinsel engelli çalışanların işleri hakkındaki görüşleri olmak üzere üç aşamada incelemektedir. Bu amaç kapsamında mevcut araştırmada aşağıdaki sorulara yanıtlar aranmıştır. 
1. Zihinsel engelli bireyler Suudi Arabistan'da kendilerini mesleğe hazırlayan programlar hakkında ne düşünüyor?

2. Suudi Arabistan'da zihinsel engelli yetişkinleri işe alma prosedürleri nelerdir?

3. Zihinsel engelli bireylerin çalıştıkları işleri ile ilgili izlenimleri nelerdir?

\section{Yöntem}

Zihinsel engelli bireylerin deneyimlerini; zihinsel engelli bireyler ve eğitim programları, zihinsel engelli bireylerin iş arama deneyimleri ve zihinsel engelli çalışanların işleri hakkındaki görüşlerini incelemeyi amaçlayan bu araştırma bir vaka çalışmasıdır. Vaka çalışmaları, araştırmacıların belirli bir durumla tutarlı olan spesifik bir konuyu belirlemelerini sağladığından avantajlıdır. Buna ek olarak, vaka çalışmaları, araştırmacının karmaşık problemleri çözme sürecine yardımcı olarak gerçek hayattaki durumlarla ilişkili karmaşık durumları ele alabilmesini sağlamaktadır (Swanborn, 2010; Thomas, 2017).

$\mathrm{Bu}$ araştırmada zihinsel engelli bireylerin iş deneyimlerini belirlemek için 10 birey seçilmiştir. $\mathrm{Bu}$ katılımcıları seçerken, Riyad İnsan Kaynakları ve Sosyal Gelişim Bakanlığı'ndan yardım alınmış ve daha sonra araştırmanın bağlamını açıklamak için ilgili ebeveynler telefonla aranmıştır. Araştırma etiği ile ilgili olarak, özellikle zihinsel engelli kişilerle görüşme konusunda, araştırmacı bu prosedürle ilgili tüm mevzuat ve protokollere uymaya çalışmıştır. Araştırma onayı Jouf Üniversitesi komitesi tarafından verilmiştir. Thomas’a göre (2017), zihinsel engelli bir kişiyle görüşürken, bu kişinin yararlı bilgiler veremeyeceğini düşünmekten kaçınmak gerekmektedir. Bu bireylerden araştırma amacıyla faydalı bilgiler elde etmek için benimsenebilecek stratejiler vardır. Hafif zihinsel engelli bireylerle iletişim kurarken dikkat edilmesi gereken en önemli faktör dildir. Birkaç çalışmanın sonuçlarının gösterdiği gibi, bu bireylere yöneltilen sorular kısa olmalıdır. Çift olumsuzluk eki içeren ifadelerin ve soyut kavramların (neden, eğer ve nasıl) kullanılmaması gerekmektedir. Görüşmeci ilk önce bireylerin uyum sağlamasını kolaylaştırmalı ve genel/gündelik sorularla konuşmaya başlamalıdır. Hafif ve orta düzeyde engelli bireylere genellikle diğer bireylerle aynı fikirde olmaları gerektiği öğretilmektedir. Bu bireylerin yanıtlarını olumsuz etkileyecek ve güvensiz hissedecekleri ifadelerden kaçınılmalıdır. Daha iyi görüşme yapabilmek için görüşmecilerin profesyonel olmaları ve temel bilişsel ve deneysel bilgiler kazanılmalarının önemli olduğu öne sürülmüştür (Hollomotz, 2018; Lewis \& Porter, 2004; Tideman \& Sevensson, 2015).

İnsan Kaynakları ve Sosyal Kalkınma Bakanlığı, ilk etapta zihinsel engelli 18 aileyle temasa geçmiş ve bu ailelerden sadece 10 'u çalışmaya seçilmiştir. Katılımcıların seçiminde erişilebilirlik göz önünde bulundurulmuştur. Bu araştırmaya katılanların gizliliğini korumak amacıyla on katılımcı, araştırma sorularının üç aşamasını temsil edecek şekilde kodlanmış ve üç gruba ayrılmıştır ve bu bölünmenin nedeni bu bireylerin bu sorularla ilgili deneyimleridir. İlk soru 'Zihinsel engelli bireyler Suudi Arabistan'da kendilerini mesleğe hazırlayan programlar hakkında ne düşünüyor?' için katılımcılara A1, A2, A3 ve A4 adları verilmiştir. İkinci 'Suudi Arabistan'da zihinsel engelli yetişkinlerin istihdamı için prosedürler nelerdir?' sorusu için katılımcılar B1, B2 ve B3 olarak isimlendirilmiştir. Son olarak, üçüncü soru 'İş hakkında engelli işçilerin izlenimleri nelerdir?' için katılımcılar C1, C2 ve C3 olarak kodlanmıştır.

Görüşme soruları yazar tarafından oluşturulmuş, Cidde Üniversitesi ve Jouf Üniversitesi Özel Eğitim bölümlerinden doktorasını tamamlamış iki uzman tarafından onaylanmıştır. İnsan Kaynakları ve Sosyal Kalkınma Bakanlığı'ndan onay alındıktan sonra, tüm katılımcılarla Riyad şehrindeki bir mesleki rehabilitasyon merkezinde veya ilgili işyerlerinde bireysel olarak yarı yapılandırılmış görüşmeler gerçekleştirilmiştir. Görüşme süreci iki hafta ve her görüşme yaklaşık 30 ila 40 dakika sürmüştür. Katılımcılar tarafından 37 görüşme sorusunun cevaplanması gerekmiştir. Görüşme, katılımcılarla yüz yüze yapılmış ve gerekli izinler alınarak ses ve video kaydı alınmıştır. Ses kayıtlarının yazılı transkripsiyonu yapılarak kodlama ve tematik analiz için kullanılmıştır.

Araştırma amacına ilişkin elde edilen verilere dayalı olarak temaların oluşturulması için içerik analizi kullanılmıştır. Bu amaca ulaşmak için, üç araştırma sorusunun analizinde Thomas'ın (2011) Tipolojisi uygulanmıştır. Analiz aynı zamanda Suudi Arabistan'da zihinsel engelli yetişkinlerin kendilerini işe hazırlayan programları, zihinsel engelli yetişkinleri işe alma prosedürlerini ve bu engelli çalışanların işleriyle ilgili izlenimlerini nasıl algıladıklarına dair anlayışı geliştirmeyi de amaçlamaktadır. Ayrıca, analizde benimsenen yaklaşım, alanyazın taramasından elde edilen kanıtları ve 10 katılımcıdan gelen görüşmelerden gelen yanıtları birleştirerek büyük ölçüde geliştirilen teorinin test edilmesine yöneliktir. Şekil 2' deki şema, bu sürecin bir temsilidir. 


\section{Adım: Alıştırma}

Bu aşamada, elde edilen verilerin yakından incelenerek görüşme yanıtları ve alanyazın taramasından elde edilen bulgular şeklinde elde edilen veriler hakkında bilgi edinilmiştir. Bu adım, bulguların alaka düzeyini ve araştırma sorununa cevap vermek için nasıl uygulanabileceğini değerlendirmek için gerekliydi.

\section{Adım: Kod Oluşturma}

Bu adım, tanımlanan kodu araştırma amaçlarıyla daha uygun hale getirmek amacıyla doğası gereği oldukça özneldir. Odak noktası, zihinsel engelli bireyleri işe hazırlayan programların algılanması, zihinsel engelli yetişkinleri işe alınma prosedürleri ve bu engelli bireylerin çalıştıkları işlerle ilgili izlenimleri ve ilgi alanlarıyla yakından ilişkili olan kodları tanımlamaktı.

\section{Adım: Tema Arama}

$\mathrm{Bu}$ adımda, bulgularda elde edilen farklı kodlar, belirli temalar oluşturmak için kümelenmiştir. Çalışmanın dayandığı teori, istenen temayı oluşturmada önemliydi.

\section{Adım: Tema İncelemesi}

Bu adım, amaçlanan teori ile ilgili olduklarından emin olmak için temalara ve alt temalara daha yakından bakmayı içeriyordu. Süreç, temaların daha net hale getirilmesi için gözden geçirilmesi ve ayarlanması için gerekliydi. Temaların araştırma sorusuyla uyumlu hale getirilmesi de bu aşamada sağlanmıştır.

\section{Adım: Tema Adlandırma}

Bu aşamada tematik analiz yapılarak temalar geliştirilmiştir.

\section{Adım: Raporun Oluşturulması}

Bu, araştırmacının temalarla ilgili örnek olarak ayrıntılı ve kapsamlı alıntılar seçmesi ve bunları araştırma soruları ve bağlantılı literatürle ilişkilendirerek araştırma sorusu/soruları ile tartışmasının beklendiği son aşamadır (Hilal \& Alabri, 2013). Bu süreç, temaların ayrıntılı tartışılmasını içerir ve bu araştırmanın bulguları içinde tartışılir.

\section{Bulgular}

Araştırma bulgularının incelenmesi ve analizinden, zihinsel engelli bireylerin, okuldan işe geçerken onlar için ciddi sorunlar yaratan problemler yaşadıkları sonucuna varılabilir. Bu sorunlar arasında güven eksikliği, uygun olmayan eğitim, yeterli istihdam olanaklarının bulunmaması, düşük maaş, insanların basmakalıp algıları ve saygı eksikliği yer almaktadır. Katılımcılar işyerinde çok sayıda zorlukla karşılaşma eğilimindedir. Bu zorluklar; beceri gelişimlerinin sınırlı düzeyde olması, işverenlerin çalışanlarına güven eksikliği duyması, düşük beceri ve düşük maaş algısı ve bir iş sorumluluğunu yerine getirememe algısıdır. Bulgular ayrıca, zihinsel engelli bireylerin hakları konusunda toplumun bilinçlendirilmesine, işverenlerin engellilere sağlanan programları uygulamasına, rehabilitasyon ve eğitim merkezlerinin iş aramayı kolaylaştırmak için web siteleri geliştirmelerine ihtiyaç duyulduğunu da göstermektedir. Bu bulgular bağlamında, Suudi Arabistan'da zihinsel engellileri mesleğe hazırlayan programların etkisiz olduğu konusunda katılımcıların çoğunluğunun hemfikir olduğu tartışılabilir. Katılımcılar, deneyimlerine dayanarak, hükümetin mevcut programların güçlendirilmesi ve diğer çalışanların zihinsel engelli kişilerin refahını artırmak için yerine getirmeleri gereken çok iş olduğunu ifade etmişlerdir.

\section{Tartışma, Sonuç ve Öneriler}

Bu araştırma bulgularına dayanarak, Suudi Arabistan hükümetinin zihinsel engelli kişilerin eğitimine ve mesleğe yönlendirilmesine yardımcı olabilecek planlanmış hedefler geliştirmesi önerilmektedir. Üstelik bu tür önlemlerin ve politikaların geliştirilmesi sadece devletle sınırlı kalmamalı, engellilere yönelik farkındalığın artırılması ve onlara daha uygun iş pozisyonları yaratılması için farklı sektörler ve kuruluşlar tarafından da sorumluluk üstlenilmelidir. Engelli bireylerin işe geçiş sürecinde karşılaştıkları kritik sorunların önemli nedenlerinden biri, engelli bireylere yönelik olumsuz algılardır. Bu bağlamda, Suudi Arabistan hükümetine okullarda ve işyerlerinde sosyal bütünleştirmenin desteklenmesine odaklanan özel politikalar geliştirmesi ve oluşturması da önerilebilir.

Ek olarak, kuruluşların engelli bireylerin istihdamlarını teşvik etmek ve kariyer gelişimlerini etkin bir şekilde kolaylaştırmak ve desteklemek için benimseyebilecekleri önlemler hakkında daha fazla araştırma yapılabilir. Gelişmiş ülkelerdeki hükümet ve kuruluşlar tarafindan alınan önlemler ve müdahaleler üzerine 
gelecekte de araştırmalar yapılabilir ve bu tür araştırmaların bulguları Suudi Arabistan'daki engelli bireylerin refahını iyileştirmek için uygulanabilir. Ayrıca, zihinsel engelli kişilerin beceri gelişimi ve kişisel gelişimi için Bilgi ve İletişim Teknolojisinin (BİT) rolü hakkında daha fazla araştırma yapılabilir.

\section{Teşekkür}

Jouf Üniversitesi Bilimsel Araştırma Dekanlığına, bu araştırmayı DSR-2021-04-0216 no'lu proje desteği ile destekledikleri için teşekkürlerimi sunuyorum.

\section{Destek}

Bu çalışma Jouf Üniversitesi, Bilimsel Araştırma Dekanlığı tarafından desteklenmiştir. 